\title{
Ignatzschineria indica sp. nov. and Ignatzschineria ureiclastica sp. nov., isolated from adult flesh flies (Diptera: Sarcophagidae)
}

Correspondence

Yogesh Shreepad Shouche yogesh@nccs.res.in

\author{
Arvind Kumar Gupta, ${ }^{1}$ Mahesh Shantappa Dharne, ${ }^{1 \dagger}$ \\ Ashraf Yusuf Rangrez, ${ }^{1}$ Pankaj Verma, ${ }^{1}$ Hemant V. Ghate, ${ }^{2}$ \\ Manfred Rohde, ${ }^{3}$ Milind Shivaji Patole ${ }^{1}$ and Yogesh Shreepad Shouche ${ }^{1,4}$ \\ ${ }^{1}$ Molecular Biology Unit, National Centre for Cell Science, Pune 411007, Maharashtra, India \\ ${ }^{2}$ Department of Zoology, Modern College of Arts, Science and Commerce, Shivajinagar, Pune \\ 411004, Maharashtra, India
${ }^{3}$ Helmholtz-Zentrum für Infektionsforschung GmbH, D-38124 Braunschweig, Germany
${ }^{4}$ Microbial Culture Collection, Hindustan Antibiotics Ltd. Complex, Pimpri, Pune 411018, Maharashtra, India

Two Gram-negative-staining, aerobic, non-motile, rod-shaped bacteria, designated strains FFA1 ${ }^{\top}$ and $\mathrm{FFA3}^{\top}$, and belonging to the class Gammaproteobacteria were isolated from the gastrointestinal tract of adult flesh flies (Diptera: Sarcophagidae). Phylogenetic analysis of $16 \mathrm{~S}$ rRNA gene sequence data placed these two strains within the genus Ignatzschineria with similarities of $98.6 \%\left(\mathrm{FFA1}^{\top}\right)$ and $99.35 \%\left(\mathrm{FFA3}{ }^{\top}\right.$ ) to lgnatzschineria larvae $\mathrm{L} 1 / 68^{\top}$. The level of gene sequence similarity between strains $F F A 1^{\top}$ and $F F A 3^{\top}$ was $99 \%, 97.15 \%$ and $78.1 \%$ based on the 16S rRNA, 23S rRNA and gyrB gene sequences, respectively. Strains FFA1 ${ }^{\top}$ and $\mathrm{FFA3}^{\top}$ shared $24 \%$ DNA-DNA relatedness. DNA-DNA hybridization revealed a very low level of relatedness between the novel strains ( $22 \%$ for strain FFA $1^{\top}$ and $44 \%$ for strain $F F A 3^{\top}$ ) and I. larvae $\mathrm{L} 1 / 68^{\top}$ genomic DNA. The respiratory quinone was $\mathrm{Q}-8$ in both novel strains. The DNA $\mathrm{G}+\mathrm{C}$ contents were $41.1 \mathrm{~mol} \%$ and $40.1 \mathrm{~mol} \%$ for strains FFA1 ${ }^{\top}$ and $F F A 3^{\top}$, respectively. The cell membrane of both strains consisted of phosphatidylglycerol, phosphatidylethanolamine, phospholipids and aminophospholipid. The major fatty acids for both strains were $\mathrm{C}_{16: 0}$, summed feature $8\left(\mathrm{C}_{18: 1} \omega 7 \mathrm{c}\right.$ and/or $\left.\mathrm{C}_{18: 1} \omega 6 c\right), \mathrm{CyC}_{19: 0} \omega 8 \mathrm{c}$ and $\mathrm{C}_{14: 0}$. The results of DNA-DNA hybridization between the two new strains and $I$. larvae $L 1 / 68^{\top}$, in combination with phylogenetic, chemotaxonomic, biochemical and electron microscopic data, demonstrated that strains FFA $1^{\top}$ and FFA $3^{\top}$ represented two novel species of the genus Ignatzschineria for which the names Ignatzschineria indica sp. nov. (type strain FFA $1^{\top}=\mathrm{DSM} 22309^{\top}=\mathrm{KCTC} 22643^{\top}=\mathrm{NCIM} 5325^{\top}$ ) and Ignatzschineria ureiclastica sp. nov. (type strain FFA3 ${ }^{\top}=$ DSM $22310^{\top}=$ KCTC $22644^{\top}=$ NCIM $5326^{\top}$ ) are proposed.
tPresent address: Environmental Microbial and Food Safety Laboratory, USDA-ARS, 10300 Baltimore Ave, BARC-W, Beltsville, MD 207052350, USA.

Abbreviations: CMCase, carboxymethylcellulase; DPG, diphosphatidylglycerol; PE, phosphatidylethanolamine; PG, phosphatidylglycerol; PS, phosphatidylserine.

The GenBank/EMBL/DDBJ accession numbers for the $16 \mathrm{~S}$ rRNA, $23 \mathrm{~S}$ rRNA and gyrB gene sequences of strains $F F A 1^{\top}$ and $F F A 3^{\top}$ are EU008088, EU008089, HM162934, HM162935, FJ966119 and FJ966120, respectively. The GenBank/EMBL/DDBJ accession numbers for $23 \mathrm{~S}$ rRNA and gyrB gene sequences of strains Ignatzschineria larvae $\mathrm{L}_{1 / 68}{ }^{\top}$ and Wohlfahrtiimonas chitiniclastica $\mathrm{S}^{\top}$ are $\mathrm{HM} 162936$, HM162937, FJ966121 and FJ966122, respectively.

Supplementary figures and tables are available with the online version of this paper.
The genus Ignatzschineria (formerly known by the illegitimate name Schineria) was first described by Tóth et al. (2001, 2007). This genus belongs to the class Gammaproteobacteria and, at present, comprises only one recognized species, Ignatzschineria larvae. This species was isolated from the first and second larval stages of an obligate parasitic fly, Wohlfahrtia magnifica (Diptera: Sarcophagidae), responsible for myiasis (Tóth et al., 2001, 2006). The genus is characterized by aerobic, Gramnegative, non-spore-forming, non-motile and regular rod-shaped bacteria. The main fatty acids are $\mathrm{C}_{18: 1}$, $\mathrm{C}_{16: 0}$ and $\mathrm{C}_{14: 0}$, the main polar lipids are phosphatidylglycerol (PG), diphosphatidylglycerol (DPG), phosphatidylethanolamine (PE) and phosphatidylserine (PS), the 
predominant respiratory quinone is $\mathrm{Q}-8$ and the $\mathrm{G}+\mathrm{C}$ content of the DNA is $42 \mathrm{~mol} \%$. A recently described gammaproteobacterium, Wohlfahrtiimonas chitiniclastica, was originally isolated from the same species of fly but belongs to a distinct lineage close to I. larvae (Tóth et al., 2008). Other bacterial species belonging to the genus Ignatzschineria have not been documented, although close relatives have been isolated from a maggot-infested wound (Maurin et al., 2007) and a diabetic foot ulcer (Roudiere et al., 2007) in a human patient suffering from myiasis and might induce bacteraemia in humans. The presence of Ignatzschineria sp. isolates and clones has been reported from diverse environmental and animal sources (Juteau et al., 2004; De Luna et al., 2009; Valiente Moro et al., 2009).

In this study, the results of an investigation using a polyphasic taxonomic approach are presented. Two bacterial strains, $\mathrm{FFA1}^{\mathrm{T}}$ and $\mathrm{FFA} 3^{\mathrm{T}}$, were isolated from the gut contents of adult flesh flies (Sarcophaga sp., Diptera: Sarcophagidae). The strains were recovered by serial dilution plating of the gut contents on Luria-Bertani agar (HiMedia) and plates were incubated at $37{ }^{\circ} \mathrm{C}$. Gram staining of both strains was performed using a Gram-stain kit (HiMedia) according to the manufacturer's instructions. The cell morphology of the strains was observed in the lag, exponential and stationary phases of growth. The motility of the cells was examined by the hanging drop method using phase-contrast microscopy (Eclipse E600; Nikon) and the semi-solid agar method. Ultrastructural investigations of strains $\mathrm{FFAl}^{\mathrm{T}}$ and $\mathrm{FFA} 3^{\mathrm{T}}$ were carried out as described by Spurr (1969) and samples were examined in a transmission electron microscope (TEM910; Zeiss) at an acceleration voltage of $80 \mathrm{kV}$. Images were recorded digitally with a Slow-Scan CCD-Camera $(1024 \times 1024$; ProScan) with ITEM-Software (Olympus Soft Imaging Solutions).

For comparative analyses, strains I. larvae $\mathrm{L} 1 / 68^{\mathrm{T}}$ and $W$. chitiniclastica $\mathrm{S}^{\mathrm{T}}$ were obtained from Dr Erika M. Tóth (Tóth et al., 2001, 2008). All of the phenotypic tests described below were performed on strains FFA $1^{\mathrm{T}}$, FFA3 ${ }^{\mathrm{T}}$ and its closest phylogenetic neighbour, I. larvae $\mathrm{L} 1 / 68^{\mathrm{T}}$, under the same experimental conditions. The growth of the strains was tested on nutrient agar, Müller-Hinton agar (MH agar), MacConkey agar, Salmonella Shigella agar, brain heart infusion agar and King's medium A base agar (HiMedia) at $37{ }^{\circ} \mathrm{C}$ for 2 days. Subcultivation, colony characteristics and the determination of optimal growth parameters (temperature, $\mathrm{pH}, \mathrm{NaCl}$ and oxygen requirement) were performed on $\mathrm{MH}$ agar at $37^{\circ} \mathrm{C}$ because of the luxuriant growth in this medium. Oxidase, catalase and Voges-Proskauer reactions were tested according to the methods of Tarrand \& Gröschel (1982) and Cowan \& Steel $(1974)$. Growth at different temperatures $(0,4,10,15,20$, $28,37,45$ and $\left.48{ }^{\circ} \mathrm{C}\right), \mathrm{NaCl}$ tolerance $(0,0.5,2,4,6,8,10$, 12 and $15 \%, \mathrm{w} / \mathrm{v})$ and $\mathrm{pH}$ values ( $\mathrm{pH} 5,6,7,7.5,8,8.5,9$, 10 and 11) were determined using $\mathrm{MH}$ agar or broth. Anaerobic jars with AnaeroHiGas Packs (LE002B;
HiMedia) were used to assess growth under anaerobic conditions. Urease activity, reduction of $\mathrm{NO}_{3}^{-}$, indole production from tryptophan, $\mathrm{H}_{2} \mathrm{~S}$ production from peptone, phosphatase activity, starch hydrolysis, caseinase, gelatinase, cellulase, pectinase, xylanase and carboxymethylcellulase (CMCase) activities were studied according to Smibert \& Krieg (1994) and Gerhardt et al. (1994). Haemolysin production was tested on ox-blood agar plates (Elek \& Levy, 1954). Utilization of citrate was checked according to the method of Simmons (1926). Chitinase activity was studied as described by Holding \& Collee (1971) and modified by Tóth et al. (2001) and O'Brien \& Colwell (1987). The classic medium of Koser (1923), as modified by Ventosa et al. (1982), was used for determination of the range of substrates used as carbon and energy or as carbon, nitrogen and energy sources. The basal medium contained: $5 \mathrm{~g} \mathrm{NaCl} \mathrm{l}^{-1}, 2 \mathrm{~g} \mathrm{KCl} \mathrm{l}^{-1}, 0.2 \mathrm{~g}$ $\mathrm{MgSO}_{4} \cdot 7 \mathrm{H}_{2} \mathrm{O} \mathrm{l}^{-1}, 1 \mathrm{~g} \mathrm{KNO}_{3} \mathrm{l}^{-1}, 1 \mathrm{~g}\left(\mathrm{NH}_{4}\right)_{2} \mathrm{HPO}_{4} \mathrm{l}^{-1}$, $0.5 \mathrm{~g} \mathrm{KH}_{2} \mathrm{PO}_{4} \mathrm{l}^{-1}$ and $0.05 \mathrm{~g}$ yeast extract $\mathrm{l}^{-1}$ (HiMedia). To this basal medium, $0.1 \%(\mathrm{w} / \mathrm{v})$ filter-sterilized substrate was added. Carbohydrates were used at a final concentration of $0.2 \%(\mathrm{w} / \mathrm{v})$. For the testing of amino acids as substrates, neither $\mathrm{KNO}_{3}$ nor $\left(\mathrm{NH}_{4}\right)_{2} \mathrm{HPO}_{4}$ were used. The organic compounds used as sole source of carbon and energy, or carbon, nitrogen and energy were: L-arabinose, D-fructose, D-glucose, $\alpha$-lactose, maltose, sucrose, Dmannitol, sodium acetate, sodium citrate, sodium butyrate, L-maleic acid, citric acid, L-alanine, L-arginine hydrochloride, L-asparagine, L-aspartic acid, L-cysteine-free base, L-cystine, L-glutamic acid, L-glutamine, L-glycine, Lhistidine hydrochloride, 4-hydroxy-L-proline, L-isoleucine, L-leucine, L-lysine hydrochloride, L-methionine, Lphenylalanine, L-proline, L-serine, L-threonine, L-tryptophan, L-tyrosine and L-valine. Results were interpreted according to Ventosa et al. (1982) after incubation at $37{ }^{\circ} \mathrm{C}$ for 3 days under aerobic conditions. The metabolism of glucose, lactose and sucrose was checked by the O/F test according to Hugh \& Leifson (1953) and was also tested on stabs of triple-sugar-iron agar (HiMedia). Fermentation of various carbohydrates was tested with carbohydrate differentiation discs (adonitol, arabinose, cellobiose, glucose, dulcitol, fructose, galactose, inositol, inulin, lactose, maltose, mannitol, mannose, raffinose, rhamnose, salicin, sorbitol, sucrose, trehalose and xylose; HiMedia) with basal media which contained phenol red as an indicator. Acid production from carbohydrates (L-arabinose, D-fructose, D-glucose, $\alpha$-lactose, maltose, sucrose and D-mannitol) was determined using phenol red base supplemented with $1 \%$ $(\mathrm{w} / \mathrm{v})$ filter-sterilized carbohydrate. Acid production from different carbohydrates was also studied using API ID 32 GN and API 50 CHE test strips (bioMérieux) according to the manufacturer's instructions. Phenylalanine deaminase activity was determined by flooding phenylalanine agar (HiMedia) after $24 \mathrm{~h}$ incubation with $1 \%(\mathrm{w} / \mathrm{v})$ ferric chloride solution. Decarboxylase activity of amino acids (L-alanine, L-arginine hydrochloride, L-asparagine, Laspartic acid, L-cysteine-free base, L-cystine, L-glutamic acid, L-glutamine, L-glycine, L-histidine hydrochloride, 
4-hydroxy-L-proline, L-isoleucine, L-leucine, L-lysine hydrochloride, L-methionine, L-phenylalanine, L-proline, L-serine, L-threonine, L-tryptophan, L-tyrosine and L-valine) were detected using decarboxylase broth base (Møller; HiMedia) as described by Møller (1954). Biochemical characteristics were determined using the Hi25 Enterobacteriaceae identification kit (HiMedia) and parts $\mathrm{A}, \mathrm{B}$ and $\mathrm{C}$ of the HiCarbohydrate kit (HiMedia), according to the manufacturer's instructions. The oxidation pattern of 95 carbon compounds was studied on Biolog GN2 plates. Susceptibility to antimicrobial compounds was determined according to the conventional Kirby-Bauer method (Bauer et al., 1966) using standard commercial antibiotic-susceptibility octadiscs (HiMedia) with varying amounts of antibiotics. Plates were incubated at $37{ }^{\circ} \mathrm{C}$ for $72 \mathrm{~h}$ under aerobic conditions and susceptibility was scored on the basis of the distance from the edge of the clear zone to the disc. The strain was considered susceptible when the diameter of the inhibition zone was $>14 \mathrm{~mm}$, intermediate at 10 $13 \mathrm{~mm}$ and resistant at $<10 \mathrm{~mm}$.

Genomic DNA extraction, PCR amplification of the $16 \mathrm{~S}$ rRNA gene and sequencing of amplicons were carried out according to the method of Rainey et al. (1996). The $23 \mathrm{~S}$ rRNA and gyrB genes from strains $\mathrm{FFAl}^{\mathrm{T}}$, $\mathrm{FFA}^{\mathrm{T}}$, I. larvae $\mathrm{L} 1 / 68^{\mathrm{T}}$ and $W$. chitiniclastica $\mathrm{S}^{\mathrm{T}}$ were amplified according to Van Camp et al. (1993) and Yamamoto \& Harayama (1995), respectively. The 16S rRNA, $23 \mathrm{~S}$ rRNA and gyrB nucleotide sequences were determined using an automated DNA sequencer (3730XL; Applied Biosystems). The 16S rRNA gene sequences of strains $\mathrm{FFAl}^{\mathrm{T}}(1525 \mathrm{bp})$ and $\mathrm{FFA3}^{\mathrm{T}}$ (1463 bp) were analysed by the NCBI-BLAST (Altschul et al., 1997) and megablast (Zhang et al., 2000) programs for the identification of closely related type strains with validly published names (Chun et al., 2007). The $23 \mathrm{~S}$ rRNA and $g y r B$ gene sequences of strain FFA $1^{\mathrm{T}}$ (2572 bp for $23 \mathrm{~S}$ rRNA and $1024 \mathrm{bp}$ for gyrB), strain FFA $^{\mathrm{T}}$ (2467 bp for 23S rRNA and 1024 bp for gyrB), $I$. larvae $\mathrm{L} 1 / 68^{\mathrm{T}}$ (2555 bp for $23 \mathrm{~S}$ rRNA and $1024 \mathrm{bp}$ for gyrB) and W. chitiniclastica $\mathrm{S}^{\mathrm{T}}$ (2487 bp for $23 \mathrm{~S}$ rRNA and 1024 bp for $g y r B$ ) were compared with respective reference gene sequences retrieved from the GenBank and EMBL databases. The $16 \mathrm{~S}$ rRNA gene sequences with the highest scores were selected for the calculation of pairwise sequence similarity using a global alignment algorithm, which was implemented at the EzTaxon server (http:// www.eztaxon.org/; Chun et al., 2007). The 16S rRNA and $23 \mathrm{~S}$ rRNA gene sequences and $g y r B$ amino acid sequences of the closest relatives were downloaded and aligned with the CLUSTAL_X program (Thompson et al., 1997). The multiple sequence alignment was edited and corrected manually using DAMBE (Xia \& Xie, 2001) and a degapped alignment of $1380 \mathrm{bp}$ each for 16S rRNA gene sequences, $2450 \mathrm{bp}$ each for 23S rRNA gene sequences and 352 amino acid sequences each for the gyrB gene were used to obtain an unambiguous sequence alignment. Evolutionary genetic distances were corrected according to the algorithm of the Kimura two-parameter model (Kimura, 1980). Tree topologies were inferred with the neighbour-joining (Saitou \& Nei, 1987) and maximum-parsimony methods (Fitch, 1971), using MEGA 3.1 (Kumar et al., 2004) with 1000 bootstrap replicates to obtain a strict consensus tree.

Cell biomass from strains $F F A 1^{\mathrm{T}}$ and $\mathrm{FFA} 3^{\mathrm{T}}$ for quinones and polar lipids analyses was obtained from cultures grown in $\mathrm{MH}$ broth for $72 \mathrm{~h}$ at $37^{\circ} \mathrm{C}$. Isoprenoid quinones were extracted according to the method of Collins et al. (1977) and the profile was investigated using HPLC (9001; HP) (Groth et al., 1997). Polar lipids were extracted from $100 \mathrm{mg}$ freeze-dried cell material using a chloroform: methanol: $0.3 \%$ aqueous $\mathrm{NaCl}$ mixture $1: 2: 0.8$ (by vol.) modified after Bligh \& Dyer (1959). The extraction solvent was stirred overnight and the cell debris pelleted by centrifugation. Polar lipids were recovered into the chloroform phase by adjusting the chloroform: methanol: $0.3 \%$ aqueous $\mathrm{NaCl}$ mixture to a ratio of $1: 1: 0.9$ (by vol.). Polar lipids were separated by two dimensional silica gel TLC (Art. No. 818 135; Macherey-Nagel) according to the method of Tindall et al. (2007). Analysis of respiratory quinones and polar lipids was carried out by the Identification Service of the DSMZ and Dr Brian Tindall, Braunschweig, Germany. For fatty acid analysis, strains $\mathrm{FFA}^{\mathrm{T}}, \mathrm{FFA} 3^{\mathrm{T}}$ and I. larvae $\mathrm{L} 1 / 68^{\mathrm{T}}$ were cultivated on $\mathrm{MH}$ agar media for $48 \mathrm{~h}$ at $37^{\circ} \mathrm{C}$. Cellular fatty acid analysis was conducted by the identification service of Royal Life Sciences, Pvt., Ltd. Briefly, cellular fatty acids were saponified, methylated and extracted according to standard protocols provided by the MIDI/Sherlock Microbial Identification System (MIDI; Microbial ID). Fatty acids were separated by GC and identified by the Microbial Identification software package (version 6; MIDI/ Sherlock). The DNA base composition was determined by disrupting the bacterial cells with a French pressure cell and purification on hydroxyapatite, according to the procedure of Cashion et al. (1977). The DNA was hydrolysed with P1 nuclease and the nucleotides were dephosphorylated using bovine alkaline phosphatase and separated by reversedphase HPLC (HP 9001) as described by Tamaoka \& Komagata (1984). The DNA G +C content was calculated from the ratio of deoxyguanosine $(\mathrm{dG})$ and thymidine $(\mathrm{dT})$ according to the method of Mesbah et al. (1989). DNADNA hybridization was performed as described by De Ley et al. (1970) with the modifications described by Huß et al. (1983) using a model Cary 100 Bio UV/VIS-spectrophotometer equipped with a Peltier-thermostatted $6 \times 6$ multicell changer and a temperature controller with in situ temperature probe (Varian).

The distribution of repetitive DNA sequences in the newly isolated strains, $\mathrm{FFA}^{\mathrm{T}}$ and $\mathrm{FFA} 3^{\mathrm{T}}$, and the closest phylogenetic relative I. larvae $\mathrm{L} 1 / 68^{\mathrm{T}}$ was examined and compared by analysis of the enterobacterial repetitive intergenic consensus (ERIC) sequences and repetitive extragenic palindromic (REP) element PCR as described by Versalovic et al. (1991). PCR amplification of bacterial genomic DNA by ERIC oligonucleotide primers, ERICIR (5' -ATGTAGATCCTGGGGATTCAC-3') and ERIC2 (5'-AAGTAAGTGACT- 
GGGGTGAGCG-3') and with REP primers, REP1R-I (5'IIIICGICGICATCIGGC-3') and REP2-I (5'-ICGICTTATCIGGCCTAC- $3^{\prime}$ ) were performed in an automated thermal cycler (Perkin-Elmer) with an initial denaturation $\left(90{ }^{\circ} \mathrm{C}\right.$, $3 \mathrm{~min}$ ) followed by 30 cycles of denaturation $\left(90^{\circ} \mathrm{C}, 30 \mathrm{~s}\right)$, annealing (ERIC, $45^{\circ} \mathrm{C}, 1 \mathrm{~min}$; REP, $40^{\circ} \mathrm{C}, 1 \mathrm{~min}$ ), and extension $\left(72{ }^{\circ} \mathrm{C}, 4 \mathrm{~min}\right)$ with a single final extension $\left(72{ }^{\circ} \mathrm{C}, 16 \mathrm{~min}\right)$. Amplicons were analysed by horizontal agarose gel electrophoresis and ethidium bromide staining. Stained gels were photographed on a GelDoc UV transilluminator (SynGene) and fingerprints were compared visually.

The morphological, physiological and biochemical characteristics of strains $\mathrm{FFAl}^{\mathrm{T}}$ and $\mathrm{FFA} 3^{\mathrm{T}}$ are given in the species description and in Table 1. Transmission electron micrographs of longitudinal sections of strains $F F A 1^{\mathrm{T}}$ and $\mathrm{FFA} 3^{\mathrm{T}}$ showed no characteristic invagination of the inner membrane or the ring-like structure as seen in I. larvae L1 $/ 68^{\mathrm{T}}$ (Tóth et al., 2001) (see Supplementary Figs S1 and S2, available in IJSEM Online). Strain $\mathrm{FFAl}^{\mathrm{T}}$ gave a negative result in tests for urease activity, $\mathrm{H}_{2} \mathrm{~S}$ production, nitrate reductase activity, acid production from D-fructose, fermentation of fructose and maltose and decarboxylation of L-lysine hydrochloride, but strain $\mathrm{FFA} 3^{\mathrm{T}}$ gave positive results. Characteristics that served to distinguish strains $\mathrm{FFA} 1^{\mathrm{T}}$ and $\mathrm{FFA} 3^{\mathrm{T}}$ from I. larvae $\mathrm{L} 1 / 68^{\mathrm{T}}$ are shown in Table 1.

The level of 16S rRNA and 23S rRNA gene sequence similarity between strains $\mathrm{FFAl}^{\mathrm{T}}$ and $\mathrm{FFA} 3^{\mathrm{T}}$ was $99 \%$ and $97.15 \%$, respectively. The highest $16 \mathrm{~S}$ rRNA gene sequence similarity values for strains $\mathrm{FFAl}^{\mathrm{T}}(98.6 \%)$ and $\mathrm{FFA3}^{\mathrm{T}}$ (99.3\%) were found with I. larvae $\mathrm{L} 1 / 68^{\mathrm{T}}$. The $16 \mathrm{~S}$ rRNA gene sequence similarity of strains $F F A 1^{\mathrm{T}}$ and $\mathrm{FFA}^{\mathrm{T}}$ was very low when compared with other representatives of the class Gammaproteobacteria (92.1-92.3\% with W. chitiniclastica $5^{\mathrm{T}} ; 87.5-87.8 \%$ with Pseudomonas tremae CFBP 6111; 87.3-87.6\% with Halothiobacillus neapolitanus DSM 581). The $23 \mathrm{~S}$ rRNA gene sequence similarity of strains $\mathrm{FFA}^{\mathrm{T}}$ and $\mathrm{FFA} 3^{\mathrm{T}}$ with I. larvae $\mathrm{L} 1 / 68^{\mathrm{T}}$ were $97.33 \%$ and $99.31 \%$, respectively. In a result that was similar to the $16 \mathrm{~S}$ rRNA gene sequence analysis, the $23 \mathrm{~S}$ rRNA gene sequences of the three strains showed a high degree of similarity. The $23 \mathrm{~S}$ rRNA gene sequence similarity of strains $\mathrm{FFAl}^{\mathrm{T}}, \mathrm{FFA}^{\mathrm{T}}$ and I. larvae $\mathrm{L} 1 / 68^{\mathrm{T}}$ with $W$. chitiniclastica $\mathrm{S}^{\mathrm{T}}$ was less than $93 \%$. However, the level of $23 \mathrm{~S}$ rRNA gene sequence similarity with respect to other closely related species found in the GenBank and EMBL databases was very low. The closest relatives of both new strains were from the genus Pseudomonas (Pseudomonas putida W619, $87 \%$ ) with $\leqslant 87 \%$ similarity. The results of the $23 \mathrm{~S}$ rRNA gene sequence comparison confirmed those obtained from the 16S rRNA gene sequence analyses and clearly supported the conclusion that strains $\mathrm{FFAl}^{\mathrm{T}}$ and FFA $3^{T}$ constituted a stable cluster separate from the other closely related species that could represent two separate species within a single genus. Based on gyrB gene sequences, the level of similarity between strains $\mathrm{FFAl}^{\mathrm{T}}$
Table 1. Differential characteristics of strains $F F A 1^{\top}$ and $\mathrm{FFA}{ }^{\top}$ compared with lgnatzschineria larvae $\mathrm{L} 1 / 68^{\top}$

Taxa: $1, \mathrm{FFAl}^{\mathrm{T}}$; $2, \mathrm{FFA3}^{\mathrm{T}}$; 3, I. larvae L1/68 ${ }^{\mathrm{T}}$. +, Positive; -, negative. All data are from the present study, except for DNA G + C contents which were carried out using the same experimental conditions. Data in parentheses were reported in the original description of the type species by Tóth et al. (2001). All taxa were able to grow on nutrient agar, MacConkey agar, Salmonella Shigella agar, brain heart infusion agar and King's medium A base agar. All were positive in tests for catalase, oxidase, phosphatase and phenylalanine deaminase and negative for Simmons' citrate, Methyl red, Voges-Proskauer, indole production, aesculin, caseinase, gelatinase, amylase, pectinase, xylanase and CMCase activities. Growth was not observed with any organic compounds (L-arabinose, D-fructose, D-glucose, $\alpha$-lactose, maltose, sucrose, D-mannitol, sodium acetate, sodium citrate, sodium butyrate, L-maleic acid, citric acid, L-alanine, L-arginine hydrochloride, L-asparagine, L-aspartic acid, L-cysteine-free base, L-cystine, L-glutamic acid, L-glutamine, L-glycine, L-histidine hydrochloride, 4-hydroxy-L-proline, L-isoleucine, L-leucine, L-lysine hydrochloride, L-methionine, L-phenylalanine, L-proline, L-serine, L-threonine, L-tryptophan, L-tyrosine and L-valine) used as sole carbon and energy or carbon, nitrogen and energy sources. Unable to metabolize glucose, lactose and sucrose for growth and also negative for ONPG ( $\beta$-galactosidase) and malonate utilization. Negative in tests for fermentation of adonitol, arabinose, cellobiose, glucose, dulcitol, galactose, inositol, inulin, lactose, mannitol, mannose, raffinose, rhamnose, salicin, sorbitol and sucrose and for trehalose carbohydrate differentiation discs. No acid production from the carbohydrates (L-arabinose, D-glucose, $\alpha$-lactose, maltose, sucrose and D-mannitol) tested. All three taxa were negative for the acid production test as determined by API ID 32 GN and API 50 CHE test strips and parts A, $\mathrm{B}$ and $\mathrm{C}$ of the HiCarbohydrate kit. No decarboxylase activity of amino acids (L-alanine, L-arginine hydrochloride, L-asparagine, L-aspartic acid, L-cysteine-free base, L-cystine, L-glutamic acid, L-glutamine, L-glycine, L-histidine hydrochloride, 4-hydroxy-L-proline, L-isoleucine, L-leucine, L-methionine, L-phenylalanine, L-proline, L-serine, L-threonine, L-tryptophan, L-tyrosine or L-valine) was seen for any of the three taxa. Oxidation of different carbon sources (Biolog GN2) and response to various antimicrobials are given in the species description and in Supplementary Tables S1 and S2.

\begin{tabular}{|lccc|}
\hline Characteristic & $\mathbf{1}$ & $\mathbf{2}$ & $\mathbf{3}$ \\
\hline Oxidation of (Biolog GN2): & & & \\
Acetic acid & + & - & - \\
cis-Aconitic acid & + & - & $-(+)$ \\
L-Alaninamide & + & - & - \\
D-Alanine & + & - & - \\
L-Alanine & + & - & - \\
L-Aspartic acid & + & - & - \\
Bromosuccinic acid & + & - & + \\
Citric acid & + & - & $-(+)$ \\
Formic acid & + & + & - \\
D-Fructose & - & + & + \\
Glycerol & + & - & - \\
DL- $\alpha$-Glycerol phosphate & + & - & - \\
Glycyl-L-aspartic acid & + & - & - \\
\hline
\end{tabular}


Table 1. cont.

\begin{tabular}{|c|c|c|c|}
\hline Characteristic & 1 & 2 & 3 \\
\hline$\alpha$-Hydroxybutyric acid & + & + & - \\
\hline$\gamma$-Hydroxybutyric acid & + & - & $-(+)$ \\
\hline Hydroxy-L-proline & + & - & - \\
\hline myo-Inositol & - & - & + \\
\hline$\alpha$-Ketobutyric acid & + & - & - \\
\hline DL-Lactic acid & + & + & - \\
\hline D-Psicose & - & - & + \\
\hline L-Pyroglutamic acid & - & - & + \\
\hline Pyruvic acid methyl ester & + & - & - \\
\hline Succinamic acid & + & - & - \\
\hline Succinic acid monomethyl ester & + & - & + \\
\hline Uridine & + & - & + \\
\hline Urocanic acid & - & - & + \\
\hline \multicolumn{4}{|l|}{ Activities of: } \\
\hline Chitinase & - & - & + \\
\hline $\mathrm{H}_{2} \mathrm{~S}$ from peptone & - & + & + \\
\hline Nitrate reductase & - & + & - \\
\hline Urease & - & + & + \\
\hline \multicolumn{4}{|l|}{ Acid production from: } \\
\hline D-Fructose & - & + & + \\
\hline \multicolumn{4}{|l|}{ Fermentation of (carbohydrate discs): } \\
\hline Maltose & - & + & - \\
\hline Fructose & - & + & + \\
\hline Xylose & - & - & + \\
\hline \multicolumn{4}{|c|}{ Decarboxylation of (decarboxylase broth, Møller): } \\
\hline L-Lysine hydrochloride & - & + & - \\
\hline \multicolumn{4}{|c|}{ Sensitivity to antimicrobials ( $\mu$ g per disc): } \\
\hline Amoxicillin/clavulanate (30) & - & + & + \\
\hline Cephotaxime (30) & + & + & - \\
\hline Ciprofloxacin (30) & + & - & + \\
\hline Kanamycin $(30)$ & + & - & + \\
\hline Nalidixic acid (30) & + & - & + \\
\hline Ofloxacin (5) & + & - & + \\
\hline Sparfloxacin (5) & + & - & + \\
\hline Tetracycline $(50)$ & + & - & + \\
\hline DNA G $+C$ content $(\mathrm{mol} \%)$ & 41.1 & 40.1 & $42^{\star}$ \\
\hline
\end{tabular}

*Data from Tóth et al. (2001).

and $\mathrm{FFA} 3^{\mathrm{T}}$ was $78.1 \%$. With respect to I. larvae $\mathrm{L} 1 / 68^{\mathrm{T}}$, the gyrB gene sequence similarity values were $78.9 \%$ and $90.6 \%$, respectively, for strains $\mathrm{FFAl}^{\mathrm{T}}$ and $\mathrm{FFA}^{\mathrm{T}}$. The analysis of the additional phylogenetic marker, $\operatorname{gyrB}$, showed that strains $F F A 1^{T}$ and $F F A 3^{T}$ could represent two separate novel species of the genus Ignatzschineria.

Phylogenetic analysis based on 16S rRNA and 23S rRNA gene sequences and $g y r B$ amino acid sequences among members of the class Gammaproteobacteria showed that strains FFA1 ${ }^{\mathrm{T}}$ and $\mathrm{FFA}^{\mathrm{T}}$ formed a coherent cluster with I. larvae L1/68 ${ }^{\mathrm{T}}$ (Figs 1, 2 and 3) with a high bootstrap-resampling value. The strains were clearly separated from other species belonging to related genera. The topologies of the phylogenetic trees built using the maximum-parsimony algorithm also supported the notion that strains $F F A 1^{\mathrm{T}}$ and $F F A 3^{T}$ could represent novel species that were phylogenetically distinct from the closely related species, I. larvae $\mathrm{L} 1 / 68^{\mathrm{T}}$ (see Supplementary Figs $\mathrm{S} 3 \mathrm{a}, \mathrm{b}$ and $\mathrm{c}$, available in IJSEM Online).

The respiratory quinone was Q-8 for both strains, which confirmed their membership of the class Gammaproteobacteria (Collins \& Jones, 1981). Q-8 was also reported as a predominant respiratory quinone for species of the genus Ignatzschineria by Tóth et al. (2001). Both strains showed similar polar lipid patterns and contained PG, PE, phospholipids (PL1-PL2) and aminophospholipid (PN) in their cell membrane (see Supplementary Figs S4a and b). The main polar lipids were essentially the same as those reported for the type species of the genus Ignatzschineria by Tóth et al. (2001). The major cellular fatty acids for both strains were $\mathrm{C}_{16: 0}$, summed feature $8\left(\mathrm{C}_{18: 1} \omega 7 \mathrm{c}\right.$ and/or $\left.\mathrm{C}_{18: 1} \omega 6 c\right), \mathrm{CyC}_{19: 0} \omega 8 c$ and $\mathrm{C}_{14: 0}$. The composition of all cellular fatty acid components of strains FFA $1^{\mathrm{T}}$ and FFA $3^{\mathrm{T}}$ were similar. The detailed fatty acid compositions of both strains and the closest phylogenetic neighbour, I. larvae $\mathrm{L} 1 / 68^{\mathrm{T}}$, are presented in Table 2 . The fatty acid profiles of both new strains were similar to that of $I$. larvae $\mathrm{L} 1 / 68^{\mathrm{T}}$, which contained predominantly the same fatty acid components with similar ratios between the different fatty acids (Table 2). The DNA G $+\mathrm{C}$ contents of strains FFA $1^{\mathrm{T}}$ $(41.1 \mathrm{~mol} \%)$ and $\mathrm{FFA3}^{\mathrm{T}}(40.1 \mathrm{~mol} \%)$ were very close to that of I. larvae L1/68 $8^{\mathrm{T}}(42 \mathrm{~mol} \%)$. All of the chemotaxonomic data supported the affiliation of both new strains to the genus Ignatzschineria.

A visual inspection of the ERIC and REP PCR amplicon fingerprint profiles showed the marked differences in the banding patterns between strains $F F A 1^{\mathrm{T}}, \mathrm{FFA}^{\mathrm{T}}$ and $I$. larvae $\mathrm{L} 1 / 68^{\mathrm{T}}$ (see Supplementary Figs S5a and b). The distinct banding patterns found among strains $F F A 1^{\mathrm{T}}$, $\mathrm{FFA3} 3^{\mathrm{T}}$ and I. larvae $\mathrm{L} 1 / 68^{\mathrm{T}}$ suggested that the ERIC and REP PCRs yielded a species-specific banding pattern for the genus Ignatzschineria. Phenotypically, strain $\mathrm{FFAl}^{\mathrm{T}}$ could be differentiated from I. larvae $\mathrm{L} 1 / 68^{\mathrm{T}}$ on the basis of its inability to produce $\mathrm{H}_{2} \mathrm{~S}$ from peptone, acid from fructose, fermentation of fructose and xylose, absence of urease and chitinase activity, ability to oxidize pyruvic acid methyl ester, acetic acid, cis-aconitic acid, citric acid, formic acid, $\alpha$-hydroxybutyric acid, $\gamma$-hydroxybutyric acid, $\alpha$-ketobutyric acid, DL-lactic acid, succinamic acid, L-alaninamide, D-alanine, L-alanine, L-aspartic acid, glycyl-L-aspartic acid, hydroxy-L-proline, glycerol and DL- $\alpha$-glycerol phosphate, inability to oxidize D-fructose, myo-inositol, D-psicose, L-pyroglutamic acid and urocanic acid, inability to decarboxylate L-lysine hydrochloride and sensitivity to cephotaxime $(30 \mu \mathrm{g})$, but resistance to amoxicillin/clavulanate $(30 \mu \mathrm{g})$. In addition, strain $\mathrm{FFA3}^{\mathrm{T}}$ differed from I. larvae $\mathrm{L} 1 / 68^{\mathrm{T}}$ in having nitrate reductase activity, lacking chitinase activity, being unable to ferment xylose, able to ferment maltose, able to oxidize formic acid, $\alpha$-hydroxybutyric acid and DL-lactic acid, being unable to oxidize myo-inositol, D-psicose, succinic acid monomethyl ester, bromosuccinic acid, L-pyroglutamic acid, urocanic 


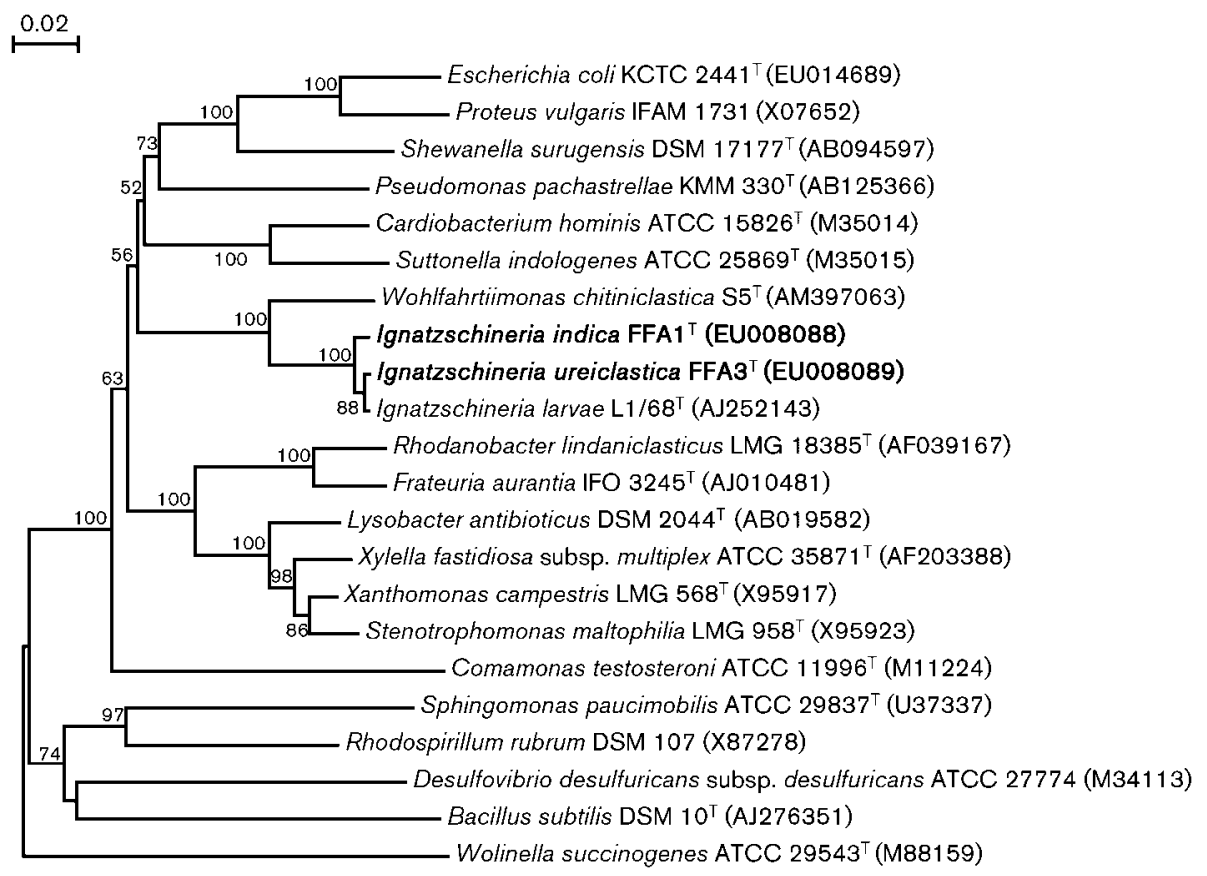

Fig. 1. Neighbour-joining phylogenetic tree based on 16S rRNA gene sequences showing the phylogenetic position of strains FFA $1^{\top}$ and FFA3 ${ }^{\top}$ among members of the class Gammaproteobacteria. GenBank accession numbers are given in parentheses. Numbers at nodes indicate percentages of bootstrap support, based on 1000 resampled datasets. Wolinella succinogenes ATCC $29543^{\top}$ was used as an outgroup. Bar, 0.02 substitutions per nucleotide position.

acid and uridine and being sensitive to cephotaxime $(30 \mu \mathrm{g})$, but resistant to ciprofloxacin $(30 \mu \mathrm{g})$, kanamycin $(30 \mu \mathrm{g})$, nalidixic acid $(30 \mu \mathrm{g})$, ofloxacin $(5 \mu \mathrm{g})$, sparfloxacin $(5 \mu \mathrm{g})$ and tetracycline $(50 \mu \mathrm{g})$. It was apparent that there were also phenotypic differences between the two novel strains (Table 1). All these differences were in agreement with the very low levels of DNA-DNA hybridization found between strains $\mathrm{FFAl}^{\mathrm{T}}$ and $\mathrm{FFA}^{\mathrm{T}}(24 \%)$ and with I. larvae $\mathrm{L} 1 / 68^{\mathrm{T}}(22 \%$ and $44 \%$, respectively). These similarity values were well below the value of $70 \%$ generally accepted as the threshold level for the delineation of a novel bacterial species (Wayne et al., 1987). This further supported the proposal of strains $F F A 1^{T}$ and $F F A 3^{T}$ as two separate species of the genus Ignatzschineria.

Therefore, the results of DNA-DNA hybridization experiments in combination with phylogenetic (16S rRNA, 23S rRNA and gyrB gene sequences), chemotaxonomic (fatty acid composition, DNA G $+\mathrm{C}$ contents and polar lipid patterns), biochemical and electron microscopy data demonstrated that the new strains represented two novel species of the genus Ignatzschineria, for which the names Ignatzschineria indica sp. nov. and Ignatzschineria ureiclastica sp. nov. are proposed.

\section{Description of Ignatzschineria indica sp. nov.}

Ignatzschineria indica (in'di.ca. L. fem. adj. indica Indian, named after source of isolation of the strain).
Cells are Gram-negative-staining, non-motile, aerobic, regular short rods $(0.8-1.8 \times 0.3-0.8 \mu \mathrm{m})$ and nonhaemolytic. Colonies grown on $\mathrm{MH}$ agar at $37{ }^{\circ} \mathrm{C}$ for $48 \mathrm{~h}$ are small $(0.5-2 \mathrm{~mm}$ in diameter), non-pigmented, entire, convex, translucent, occur singly and are able to grow on nutrient agar, MacConkey agar, Salmonella Shigella agar, brain heart infusion agar and King's medium A base agar. Catalase and oxidase reactions are positive. The temperature, $\mathrm{NaCl}$ and $\mathrm{pH}$ ranges for growth are 4$45{ }^{\circ} \mathrm{C}, 0-6 \% \mathrm{NaCl}(\mathrm{w} / \mathrm{v})$ and $\mathrm{pH} 6-9$, respectively, with optima of $37{ }^{\circ} \mathrm{C}, 2 \% \mathrm{NaCl}(\mathrm{w} / \mathrm{v})$ and 7.5 , respectively. Positive for phosphatase activity and the phenylalanine deaminase reaction. Negative results in tests for urease, $\mathrm{H}_{2} \mathrm{~S}$ production, nitrate reductase, aesculin, caseinase, gelatinase, amylase, pectinase, xylanase, CMCase and chitinase activity. Indole production, Methyl red, Voges-Proskauer and Simmons' citrate tests are negative. Based on Biolog tests, gives a positive result for oxidation of L-histidine, L-leucine, formic acid, $\alpha$-ketoglutaric acid, L-phenylalanine, DL-lactic acid, L-asparagine, $\alpha$-hydroxybutyric acid, L-glutamic acid, succinic acid, glycyl L-glutamic acid, acetic acid, bromosuccinic acid, cis-aconitic acid, succinamic acid, hydroxy-L-proline, citric acid, $\alpha$-ketobutyric acid, uridine, L-alaninamide, D-alanine, L-alanine, L-proline, L-aspartic acid, glycerol, DL- $\alpha$-glycerol phosphate, pyruvic acid methyl ester, glycyl L-aspartic acid, succinic acid monomethyl ester and $\gamma$-hydroxybutyric acid, but negative for $\alpha$-cyclodextrin, dextrin, glycogen, Tween 40 , Tween 80 , 


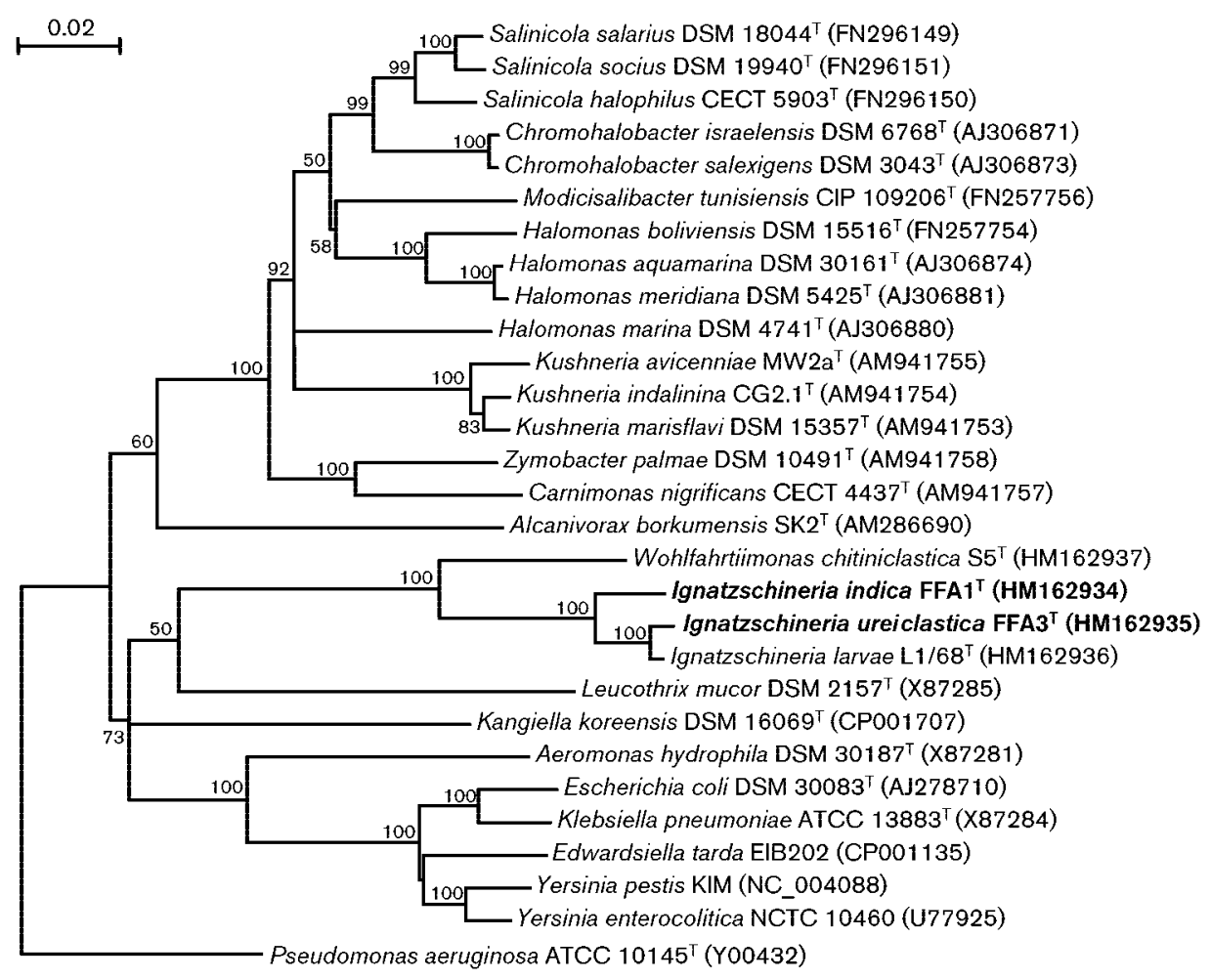

Fig. 2. Neighbour-joining phylogenetic tree based on $23 S$ rRNA gene sequences showing the phylogenetic position of strains FFA $1^{\top}$ and FFA3 ${ }^{\top}$ among members of the class Gammaproteobacteria. GenBank accession numbers are given in parentheses. Numbers at nodes indicate percentages of bootstrap support, based on analysis of 1000 resampled datasets. Pseudomonas aeruginosa ATCC $10145^{\top}$ was used as an outgroup. Bar, 0.02 substitutions per nucleotide position.

$\mathrm{N}$-acetyl-D-galactosamine, $\mathrm{N}$-acetyl-D-glucosamine, adonitol, L-arabinose, D-arabitol, cellobiose, i-erythritol, $D$-fructose, L-fucose, D-galactose, gentiobiose, $\alpha$-D-glucose, myo-inositol, $\alpha$-lactose, lactulose, maltose, D-mannitol, D-mannose, melibiose, methyl $\beta$-D-glucoside, D-psicose, raffinose, L-rhamnose, D-sorbitol, sucrose, trehalose, turanose, xylitol, D-galactonic acid lactone, D-galacturonic acid, D-gluconic acid, D-glucosaminic acid, D-glucuronic acid, $\beta$-hydroxybutyric acid, $p$-hydroxyphenylacetic acid, itaconic acid, $\alpha$-ketovaleric acid, malonic acid, propionic acid, quinic acid, D-saccharic acid, sebacic acid, glucuronamide, L-alanylglycine, L-ornithine, L-pyroglutamic acid, D-serine, L-serine, L-threonine, DL-carnitine, $\gamma$ aminobutyric acid, urocanic acid, inosine, thymidine, phenylethylamine, putrescine, 2-aminoethanol, 2,3-butanediol, $\alpha$-D-glucose 1-phosphate and $\alpha$-D-glucose 6-phosphate. No acid production from API ID 32 GN or API 50 CHE test strips or parts A, B and C of the HiCarbohydrate kit. The

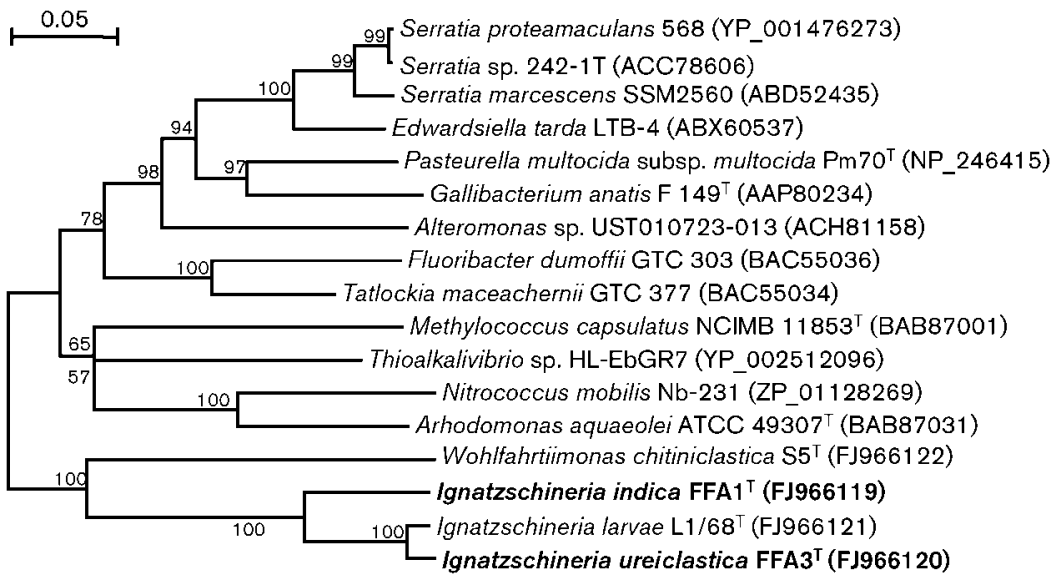

Fig. 3. Neighbour-joining phylogenetic tree based on $g y r B$ amino acid sequences showing the phylogenetic position of strains $F F A 1^{\top}$ and FFA3 $^{\top}$ among members of the class Gammaproteobacteria. GenBank accession numbers are given in parentheses. Numbers at nodes indicate percentages of bootstrap support, based on 1000 resampled datasets. Bar, 0.05 substitutions per amino acid position. 
Table 2. Fatty acid composition of strains $F F A 1^{\top}, F F A 3^{\top}$ and I. larvae $\mathrm{L} 1 / 68^{\top}$

Taxa: $1, \mathrm{FFAl}^{\mathrm{T}} ; 2, \mathrm{FFA}^{\mathrm{T}} ; 3$, I. larvae $\mathrm{L} 1 / 68^{\mathrm{T}}$. Data are from the present study and represent percentages of total fatty acids. Fatty acids amounting to $<1 \%$ of the total fatty acids in all strains are omitted. Major fatty acids $(>10 \%)$ are shown in bold. The cellular fatty acids for strains $\mathrm{FFA} 1^{\mathrm{T}}, \mathrm{FFA} 3^{\mathrm{T}}$ and I. larvae $\mathrm{L} 1 / 68^{\mathrm{T}}$ were determined after cultivation on $\mathrm{MH}$ agar at $37{ }^{\circ} \mathrm{C}$ for 2 days.

\begin{tabular}{|lrrr|}
\hline Fatty acid & \multicolumn{1}{c}{$\mathbf{1}$} & \multicolumn{1}{c|}{$\mathbf{2}$} & \multicolumn{1}{c|}{$\mathbf{3}$} \\
\hline $\mathrm{C}_{14: 0}$ & $\mathbf{1 1 . 8}$ & $\mathbf{1 4 . 8}$ & $\mathbf{1 1 . 6}$ \\
$\mathrm{C}_{16: 0}$ & $\mathbf{3 3 . 8}$ & $\mathbf{3 1 . 6}$ & $\mathbf{2 6 . 9}$ \\
$\mathrm{C}_{12: 0} 3-\mathrm{OH}$ & 3.6 & 3.0 & 3.2 \\
CyC $_{19: 0} \omega 8 c$ & $\mathbf{1 5 . 9}$ & $\mathbf{1 9 . 5}$ & $\mathbf{1 4 . 9}$ \\
Summed features $^{*}$ & & & \\
2 & 2.4 & 2.1 & 2.2 \\
3 & 2.3 & 2.4 & 1.9 \\
8 & $\mathbf{2 5 . 0}$ & $\mathbf{2 1 . 6}$ & $\mathbf{3 3 . 8}$ \\
\hline
\end{tabular}

*Summed features are groups of two or three fatty acids that could not be separated by GLC using the MIDI system. Summed feature 2 comprised $\mathrm{C}_{16: 1}$ iso I and/or $\mathrm{C}_{14: 0} 3-\mathrm{OH}$; summed feature 3 comprised $\mathrm{C}_{16: 1} \omega 7 c$ and/or $\mathrm{C}_{16: 1} \omega 6 c$ and summed feature 8 comprised $\mathrm{C}_{18: 1} \omega 7 c$ and/or $\mathrm{C}_{18: 1} \omega 6 c$.

major cellular fatty acids are $\mathrm{C}_{16: 0}$, summed feature 8 $\left(\mathrm{C}_{18: 1} \omega 7 c\right.$ and/or $\left.\mathrm{C}_{18: 1} \omega 6 c\right), \mathrm{CyC}_{19: 0} \omega 8 c$ and $\mathrm{C}_{14: 0}$. The respiratory quinone is Q-8. Polar lipids are PG, PE, PL1, PL2 and PN. Susceptible to $(\mu \mathrm{g})$ : amikacin (30), azithromicin (15), cefaclor (30), ceftriaxone (30), cephotaxime (30), chloramphenicol (30), ciprofloxacin (30), clindamycin (2), erythromycin (15), gentamicin (10), kanamycin (30), nalidixic acid (30), netillin (30), nitrofurantoin (300), norfloxacin (10), ofloxacin (5), piperacillin/tazobactum (100/10), sparfloxacin (5), streptomycin (25), tetracycline (50) and tobramycin (10), but resistant to ampicillin (10), amoxicillin/clavulanate (30), aztreonam (30), cephalothin (5), colistin (50), mecillinam (25), metronidazole (5), penicillin (10 units), teicoplanin (30), ticarcillin (75) and vancomycin (30). Shows intermediate resistance to carbenicillin (30), ceftazidime (100), cephalexin (30), cephoxitin (30), colistin methane sulphate (25), co-trimoxazole (25), doxycycline hydrochloride (30), gatifloxacin (30), sulphamethoxazole (25), sulphatriad (200) and trimethoprin (1.25).

The type strain, FFAl $^{\mathrm{T}} \quad\left(=\mathrm{DSM} \quad 22309^{\mathrm{T}}=\mathrm{KCTC}\right.$ $22643^{\mathrm{T}}=$ NCIM $5325^{\mathrm{T}}$ ), was isolated from the gut contents of the adult flesh fly (Diptera: Sarcophagidae). DNA G + C content of the type strain is $41.1 \mathrm{~mol} \%$.

\section{Description of Ignatzschineria ureiclastica sp. nov.}

Ignatzschineria ureiclastica [u.re.i.clas'ti.ca. N.L. n. urea, urea; N.L. adj. clasticus - $a-u m$ (from Gr. adj. klastos - $\hat{e}$-on) broken in pieces, breaking; N.L. fem. adj. ureiclastica breaking urea].
Cells are Gram-negative-staining, non-motile, aerobic, regular short rods $(1-2 \times 0.5-1 \mu \mathrm{m})$ and non-haemolytic. Colonies grown on $\mathrm{MH}$ agar at $37{ }^{\circ} \mathrm{C}$ for $48 \mathrm{~h}$ are small (0.5-2.5 mm in diameter), non-pigmented, entire, convex, translucent, occur singly and are able to grow on nutrient agar, MacConkey agar, Salmonella Shigella agar, brain heart infusion agar and King's medium A base agar. Catalase and oxidase reactions are positive. The temperature, $\mathrm{NaCl}$ and $\mathrm{pH}$ ranges for growth are $4-45{ }^{\circ} \mathrm{C}, 0-6 \%$ $\mathrm{NaCl}(\mathrm{w} / \mathrm{v})$ and $\mathrm{pH} 6-9$, respectively, with optima of $37{ }^{\circ} \mathrm{C}, 2 \% \mathrm{NaCl}(\mathrm{w} / \mathrm{v})$ and $\mathrm{pH} 7.5$, respectively. Positive for urease, $\mathrm{H}_{2} \mathrm{~S}$ production, nitrate reductase, phosphatase activity and phenylalanine deaminase reaction. Negative for aesculin, caseinase, gelatinase, amylase, pectinase, xylanase, CMCase and chitinase activity. Tests for indole production, Methyl red, Voges-Proskauer and Simmons' citrate are negative. Based on Biolog tests, gives a positive result for oxidation of L-histidine, L-leucine, formic acid, $\alpha$-ketoglutaric acid, L-phenylalanine, DL-lactic acid, $\mathrm{D}$-fructose, L-asparagine, $\alpha$-hydroxybutyric acid, L-glutamic acid, succinic acid and glycyl L-glutamic acid, but negative reaction for acetic acid, bromosuccinic acid, cis-aconitic acid, succinamic acid, hydroxy-L-proline, citric acid, $\alpha$-ketobutyric acid, uridine, L-alaninamide, D-alanine, L-alanine, L-proline, L-aspartic acid, glycerol, DL- $\alpha$-glycerol phosphate, pyruvic acid methyl ester, glycyl L-aspartic acid, succinic acid monomethyl ester, $\gamma$-hydroxybutyric acid, $\alpha$-cyclodextrin, dextrin, glycogen, Tween 40 , Tween 80 , $\mathrm{N}$-acetyl-D-galactosamine, $\mathrm{N}$-acetyl-D-glucosamine, adonitol, L-arabinose, D-arabitol, cellobiose, i-erythritol, L-fucose, D-galactose, gentiobiose, $\alpha$-D-glucose, myo-inositol, $\alpha$-lactose, lactulose, maltose, D-mannitol, D-mannose, melibiose, methyl $\beta$-D-glucoside, D-psicose, raffinose, L-rhamnose, D-sorbitol, sucrose, trehalose, turanose, xylitol, D-galactonic acid lactone, D-galacturonic acid, D-gluconic acid, D-glucosaminic acid, D-glucuronic acid, $\beta$-hydroxybutyric acid, $p$-hydroxyphenylacetic acid, itaconic acid, $\alpha$ ketovaleric acid, malonic acid, propionic acid, quinic acid, D-saccharic acid, sebacic acid, glucuronamide, L-alanylglycine, L-ornithine, L-pyroglutamic acid, D-serine, L-serine, L-threonine, DL-carnitine, $\gamma$-aminobutyric acid, urocanic acid, inosine, thymidine, phenylethylamine, putrescine, 2aminoethanol, 2,3-butanediol, $\alpha$-D-glucose 1-phosphate and $\alpha$-D-glucose 6-phosphate. No acid production from API ID $32 \mathrm{GN}$ or API 50 CHE test strips or parts A, B and C of the HiCarbohydrate kit. Able to decarboxylate L-lysine hydrochloride amino acid (decarboxylase broth Base, Møller) and ferment fructose and maltose (carbohydrate differentiation discs). The major cellular fatty acids are $\mathrm{C}_{16: 0}$, summed feature $8 \quad\left(\mathrm{C}_{18: 1} \omega 7 c\right.$ and/or $\left.\mathrm{C}_{18: 1} \omega 6 c\right), \mathrm{CyC}_{19: 0} \omega 8 c$ and $\mathrm{C}_{14: 0}$. The respiratory quinone is Q-8. Polar lipids are PG, PE, PL1, PL2 and PN. Susceptible to ( $\mu \mathrm{g})$ : amikacin (30), amoxicillin/clavulanate (30), ceftriaxone (30), cephotaxime (30), chloramphenicol (30), clindamycin (2), netillin (30), nitrofurantoin (300), streptomycin (25) and tobramycin (10), but resistant to ampicillin (10), aztreonam (30), ceftazidime (100), ciprofloxacin (30), colistin (50), doxycyclin hydrochloride (30), kanamycin (30), mecillinam (25), 
metronidazole (5), nalidixic acid (30), ofloxacin (5), penicillin (10 U), piperacillin/tazobactum (100/10), sparfloxacin (5), sulphamethoxazole (25), sulphatriad (200), teicoplanin (30), ticarcillin (75), tetracycline (50) and vancomycin (30). It shows intermediate resistance to azithromicin (15), carbenicillin (30), cefaclor (30), cephalexin (30), cephalothin (5), cephoxitin (30), colistin methane sulphate (25), co-trimoxazole (25), erythromycin (15), gatifloxacin (30), gentamicin (100), norfloxacin (10) and trimethoprin (1.25).

The type strain, FFA $^{\mathrm{T}} \quad\left(=\mathrm{DSM} \quad 22310^{\mathrm{T}}=\mathrm{KCTC}\right.$ $22644^{\mathrm{T}}=$ NCIM $\left.5326^{\mathrm{T}}\right)$, was isolated from the gut contents of an adult flesh fly (Diptera: Sarcophagidae). The DNA $\mathrm{G}+\mathrm{C}$ content of the type strain is $40.1 \mathrm{~mol} \%$.

\section{Acknowledgements}

We thank the Director of the National Centre for Cell Science (NCCS), Pune, India, for facilities, encouragement and support. Grants from Department of Biotechnology, New Delhi, supported this research. A research fellowship awarded by the Council of Scientific and Industrial Research (CSIR), New Delhi, to A. K. G, is gratefully acknowledged. We are grateful to Dr Erika M. Tóth (Department of Microbiology, Eötvös Loránd University, Hungary) for sharing isolates (Ignatzschineria larvae $\mathrm{L} 1 / 68^{\mathrm{T}}$, Wohlfahrtiimonas chitiniclastica $\mathrm{S}^{\mathrm{T}}$ ) and Professor Dr Erko Stackebrandt and Dr Cathrin Spröer (DSMZ-Deutsche Sammlung von Mikro-organismen und Zellkulturen, Germany) for providing valuable ideas and comments in the initial stage of the study. Special thanks to Dr Tapan Chakrabarti (Microbial Culture Collection, Pune, India), Dr Gurdeep Rastogi (UC Davis, CA, USA), Dr Kamlesh Jangid (Georgia University, GA, USA), Dr Parag Vaishampayan (JPL, NASA, LA, USA) and Mrs Pragati Gupta for their helpful comments in preparing the manuscript.

\section{References}

Altschul, S. F., Madden, T. L., Schäffer, A. A., Zhang, J., Zhang, Z., Miller, W. \& Lipman, D. J. (1997). Gapped BLAST and PSI-BLAST: a new generation of protein database search programs. Nucleic Acids Res 25, 3389-3402.

Bauer, A. W., Kirby, W. M. M., Sherris, J. C. \& Turck, M. (1966). Antibiotic susceptibility testing by a standardized single disk method. Am J Clin Pathol 45, 493-496.

Bligh, E. G. \& Dyer, W. J. (1959). A rapid method of total lipid extraction and purification. Can J Biochem Physiol 37, 911917.

Cashion, P., Holder-Franklin, M. A., McCully, J. \& Franklin, M. (1977). A rapid method for the base ratio determination of bacterial DNA. Anal Biochem 81, 461-466.

Chun, J., Lee, J.-H., Jung, Y., Kim, M., Kim, S., Kim, B. K. \& Lim, Y. W. (2007). EzTaxon: a web-based tool for the identification of prokaryotes based on $16 \mathrm{~S}$ ribosomal RNA gene sequences. Int J Syst Evol Microbiol 57, 2259-2261.

Collins, M. D. \& Jones, D. (1981). Distribution of isoprenoid quinone structural types in bacteria and their taxonomic implication. Microbiol Rev 45, 316-354.

Collins, M. D., Pirouz, T., Goodfellow, M. \& Minnikin, D. E. (1977). Distribution of menaquinones in actinomycetes and corynebacteria. J Gen Microbiol 100, 221-230.
Cowan, S. T. \& Steel, K. J. (1974). Manual for the Identification of Medical Bacteria. London: Cambridge University Press.

De Ley, J., Cattoir, H. \& Reynaerts, A. (1970). The quantitative measurement of DNA hybridization from renaturation rates. Eur $J$ Biochem 12, 133-142.

De Luna, C. J., Moro, C. V., Guy, J. H., Zenner, L. \& Sparagano, O. A. (2009). Endosymbiotic bacteria living inside the poultry red mite (Dermanyssus gallinae). Exp Appl Acarol 48, 105-113.

Elek, S. D. \& Levy, E. (1954). The nature of discrepancies between haemolysins in culture filtrates and plate haemolysin patterns of staphylococci. J Pathol Bacteriol 68, 31-40.

Fitch, W. M. (1971). Toward defining the course of evolution: minimum change for specific tree topology. Syst Zool 20, 406-416.

Gerhardt, P., Murray, R. G. E., Wood, W. A. \& Krieg, N. R. (1994). Methods for General and Molecular Bacteriology. Washington, DC: American Society for Microbiology.

Groth, I., Schumann, P., Rainey, F. A., Martin, K., Schuetze, B. \& Augsten, K. (1997). Demetria terragena gen. nov., sp. nov., a new genus of actinomycetes isolated from compost soil. Int J Syst Bacteriol 47, 1129-1133.

Holding, A. J. \& Collee, J. G. (1971). Routine biochemical tests. Methods Microbiol 6A, 1-5.

Hugh, R. \& Leifson, E. (1953). The taxonomic significance of fermentative versus oxidative metabolism of carbohydrates by various gram negative bacteria. J Bacteriol 66, 24-26.

Huß, V. A. R., Festl, H. \& Schleifer, K. H. (1983). Studies on the spectrophotometric determination of DNA hybridization from renaturation rates. Syst Appl Microbiol 4, 184-192.

Juteau, P., Tremblay, D., Villemur, R., Bisaillon, J. G. \& Beaudet, R. (2004). Analysis of the bacterial community inhabiting an aerobic thermophilic sequencing batch reactor (AT-SBR) treating swine waste. Appl Microbiol Biotechnol 66, 115-122.

Kimura, M. (1980). A simple method for estimating evolutionary rates of base substitutions through comparative studies of nucleotide sequences. J Mol Evol 16, 111-120.

Koser, S. A. (1923). Utilization of the salts of organic acids by the colon-aerogenes group. J Bacteriol 8, 493-520.

Kumar, S. K., Tamura, K. \& Nei, M. (2004). MEGA3: Integrated software for Molecular Evolutionary Genetics Analysis and sequence alignment. Brief Bioinform 5, 150-163.

Maurin, M., Delbano, J. N., Mackaya, L., Colomb, H., Guier, C., Mandjee, A., Recule, C. \& Croize, J. (2007). Human infection with Schineria larvae. Emerg Infect Dis 13, 657-659.

Mesbah, M., Premachandran, U. \& Whitman, W. B. (1989). Precise measurement of the $\mathrm{G}+\mathrm{C}$ content of deoxyribonucleic acid by high performance liquid chromatography. Int J Syst Bacteriol 39, 159-167.

Møller, V. (1954). Activity determination of amino acid decarboxylases in Enterobacteriaceae. Acta Pathol Microbiol Scand 34, 102-114.

O'Brien, M. \& Colwell, R. R. (1987). A rapid test for chitinase activity that uses 4-methylumbelliferyl- $N$-acetyl- $\beta$-D-glucosaminide. Appl Environ Microbiol 53, 1718-1720.

Rainey, F. A., Ward-Rainey, N., Kroppenstedt, R. M. \& Stackebrandt, E. (1996). The genus Nocardiopsis represents a phylogenetically coherent taxon and a distinct actinomycete lineage: proposal of Nocardiopsaceae fam. nov. Int J Syst Bacteriol 46, 1088-1092.

Roudiere, L., Jean-Pierre, H., Comte, C., Zorgniotti, I., Marchandin, H. \& Jumas-Bilak, E. (2007). Isolation of Schineria sp. from a man. Emerg Infect Dis 13, 659-661.

Saitou, N. \& Nei, M. (1987). The neighbor-joining method: a new method for reconstructing phylogenetic trees. Mol Biol Evol 4, 406425. 
Simmons, J. S. (1926). A culture medium for differentiating organisms of typhoid colon aerogenes groups and for isolation of certain fungi. J Infect Dis 39, 209-214.

Smibert, R. M. \& Krieg, N. R. (1994). Phenotypic characterisation. In Methods for General and Molecular Bacteriology, pp. 603-711. Edited by P. Gerhardt, R. G. E. Murray, W. A. Wood \& N. R. Krieg. Washington, DC: American Society for Microbiology.

Spurr, A. R. (1969). A low-viscosity epoxy resin embedding medium for electron microscopy. J Ultrastruct Res 26, 31-43.

Tamaoka, J. \& Komagata, K. (1984). Determination of DNA base composition by reversed-phase high-performance liquid chromatography. FEMS Microbiol Lett 25, 125-128.

Tarrand, J. J. \& Gröschel, D. H. M. (1982). Rapid, modified oxidase test for oxidase-variable bacterial isolates. J Clin Microbiol 16, 772-774.

Thompson, J. D., Gibson, T. J., Plewniak, F., Jeanmougin, F. \& Higgins, D. G. (1997). The CLUSTAL_X windows interface: flexible strategies for multiple sequence alignment aided by quality analysis tools. Nucleic Acids Res 25, 4876-4882.

Tindall, B. J., Sikorski, J., Smibert, R. M. \& Kreig, N. R. (2007). Phenotypic characterization and the principles of comparative systematics. In Methods for General and Molecular Microbiology, 3rd edn, pp. 330-393. Edited by C. A. Reddy, T. J. Beveridge, J. A. Breznak, G. Marzluf, T. M. Schmidt \& L. R. Snyder. Washington, DC: American Society for Microbiology.

Tóth, E., Kovács, G., Schumann, P., Kovács, A. L., Steiner, U., Halbritter, A. \& Márialigeti, K. (2001). Schineria larvae gen. nov., sp. nov., isolated from the 1st and 2nd larval stages of Wohlfahrtia magnifica (Diptera: Sarcophagidae). Int J Syst Evol Microbiol 51, 401-407.

Tóth, E. M., Hell, E., Kovács, G., Borsodi, A. K. \& Márialigeti, K. (2006). Bacteria isolated from the different developmental stages and larval organs of the obligate parasitic fly, Wohlfahrtia magnifica (Diptera: Sarcophagidae). Microb Ecol 51, 13-21.

Tóth, E. M., Borsodi, A. K., Euzéby, J. P., Tindall, B. J. \& Márialigeti, K. (2007). Proposal to replace the illegitimate genus name Schineria Toth et al. 2001 with the genus name Ignatzschineria gen. nov. and to replace the illegitimate combination Schineria larvae Toth et al. 2001 with Ignatzschineria larvae comb. nov. Int J Syst Evol Microbiol 57, 179-180.

Tóth, E. M., Schumann, P., Borsodi, A. K., Kéki, Z., Kovács, A. L. \& Márialigeti, K. (2008). Wohlfahrtiimonas chitiniclastica gen. nov., sp. nov., a new gammaproteobacterium isolated from Wohlfahrtia magnifica (Diptera: Sarcophagidae). Int J Syst Evol Microbiol 58, 976-981.

Valiente Moro, C., Thioulouse, J., Chauve, C., Normand, P. \& Zenner, L. (2009). Bacterial taxa associated with the hematophagous mite Dermanyssus gallinae detected by $16 \mathrm{~S}$ rRNA PCR amplification and TTGE fingerprinting. Res Microbiol 160, 63-70.

Van Camp, G., Chapelle, S. \& De Wachter, R. (1993). Amplification and sequencing of variable regions in bacterial $23 \mathrm{~S}$ ribosomal RNA genes with conserved primer sequences. Curr Microbiol 27, 147-151.

Ventosa, A., Quesada, E., Rodriguez-Valera, F., Ruiz-Berraquero, F. \& Ramos-Cormenzana, A. (1982). Numerical taxonomy of moderately halophilic Gram-negative rods. J Gen Microbiol 128, 1959-1968.

Versalovic, J., Koeuth, T. \& Lupski, J. R. (1991). Distribution of repetitive DNA sequences in eubacteria and application to fingerprinting of bacterial genomes. Nucleic Acids Res 19, 6823-6831.

Wayne, L. G., Brenner, D. J., Colwell, R. R., Grimont, P. A. D., Kandler, O., Krichevsky, M. I., Moore, L. H., Moore, W. E. C., Murray, R. G. E. \& other authors (1987). Report of the ad hoc committee on reconciliation of approaches to bacterial systematics. Int J Syst Bacteriol 37, 463-464.

Xia, X. \& Xie, Z. (2001). DAMBE: software package for data analysis in molecular biology and evolution. J Hered 92, 371-373.

Yamamoto, S. \& Harayama, S. (1995). PCR amplification and direct sequencing of $g y r B$ genes with universal primers and their application to the detection and taxonomic analysis of Pseudomonas putida strains. Appl Environ Microbiol 61, 1104-1109.

Zhang, Z., Schwartz, S., Wagner, L. \& Miller, W. (2000). A greedy algorithm for aligning DNA sequences. J Comput Biol 7, 203-214. 